\title{
RISK FACTORS FOR MULTIPLE SCLEROSIS IN VOLYN REGION (UKRAINE)
}

\author{
Nataliia Bobryk \\ Department of Neurology \\ Volyn Regional Hospital \\ 21 Grushevskogo ave., Lutsk, Ukraine, 43005 \\ zagorulka@mail.ru \\ Larysa Sokolova \\ Department of Neurology \\ O. O. Bogomolets National Medical University \\ 13 T. Shevchenko blvd., Kyiv, Ukraine, 01601
}

\begin{abstract}
The prevalence rate of multiple sclerosis (MS) in Volyn Region (101.0 per 100000) is the highest in Ukraine. To study MS risk factors in Volyn Region, special questionnaires were distributed among all MS patients residing in Volyn region. Results were obtained from 227 respondents including 154 women and 73 men of mean age $43 \pm 10.6$ years. The control group included 105 healthy respondents inhabiting Volyn region.

We found associated risk factors for MS to be: mother of Volyn origin, maternal age after 27 years old and paternal age after 29 years old at birth of respondent, subject's born as a third child, brestfeeding for less than one year, living in the zone of industrial pollution, near mobile, TV- and radio re-translators, full traffic automobile roads, time spending outdoors less than one hour in winter and less than eight hours in summer, consumption of fruit and vegetables less than 5 times a week, of beef less than 3 times a week, poultry meet less than 3, berries less than 3, cereals less than 4 times a week, chronic stressful situations in life.

Patients with MS more frequently reported AVRI, hepatitis and herpes simplex virus. Among patients with MS there were fewer respondents with history of chickenpox, rubella and DPT (diphtheria, pertussis, tetanus), BCG immunizations.

Here, we introduced a novel study of MS risk factors within Volyn Region. The Registry established in 2012 is being constantly updated and can be a database for a long-term retrospective study involving a large number of patients.
\end{abstract}

Keywords: multiple sclerosis, risk factors, Volyn Region.

\section{Introduction}

Multiple sclerosis (MS) is an organ-specific autoimmune disorder which develops in genetically susceptible individuals as a result ofthe influence of environmental factors [1]. The results of studies of MS familial cases show evidence for a significant maternal genome effect on MS occurrence. Risk of MS increases if the maternal origin is a zone of the high prevalence of the disease [1, 2]. Environmental factors impacting the genetic susceptibility to MS are unknown. Numerous epidemiological studies are being conducted to determine the causes and mechanisms of MS development.

Environmental factors influencing and causing the susceptibility to MS occur both in the pre- and postnatal periods. The parents' age at their child birth, number of older sibs, birth in the urban or rural areas, duration of breastfeeding and related insufficiency of serum vitamin D are the possible causes of MS described in the medical literature [3].

Frequent childhood infections reduce susceptibility to MS [4]. According to the so-called 'hygiene hypothesis' modern living conditions in the industrialized countries isolate infants and children from many infectious challenges and are required for the development of appropriate immunoregulatory networks. An altered sequence of infections may generate and maintain a deficit within the immunological network preceding the onset of MS for years or decades [5]. The frequency of allergic reactions in patients suffering from MS is lower than in other respondents $[6,3]$. The meta-analysis of effects of various immunizations on MS risk in adults (BCG, chickenpox, diphtheria, haemophilus influenza B (Hib), hepatitis A, B, influenza, Japanese encephalitis, measles, mumps, pertussis, polio, rabies rotavirus, rubella, tetanus, typhoid fever, yellow fever) shows that 
none of them is associated with higher risk. In fact, diphtheria and tetanus immunizations may be associated with a lower risk of MS. [7].

The WHO (World Health Organization) report 2008 clearly indicates that MS has a geographical distribution corresponding to countries with hyper caloric, high-fat/high carbohydrate diets and reduced exposure to the ultraviolet sunlight. Accordingly, a study by the North American Research Committee on Multiple Sclerosis (NARCOMS) has recently found that a quarter of the patients were obese and $31.3 \%$ were overweight [8].

Adverse ecological conditions of living may be an exogenous causative factor realizing the genetic susceptibility to MS. It was the deterioration of the ecological environment that had caused the high rate of MS in Sardinia, Norway, Canada and the USA in the 60s and 90s of the previous century. Scientific publications of the 90s mentioned the MS prevalence growth in Europe associated with opening of factories [9-11].

Epidemiological studies are highly informative to understand the nature, contribution and interaction of genetic and environmental factors in MS [1].

\section{Aim}

The aim of investigation is evaluating of potential risk factors of multiple sclerosis, described in the others international scientific sources, for inhabitants of Volyn region

\section{Materials and Methods}

Volyn Region is situated in the northwestern part of Ukraine. It borders with the Poland Republic in the West. The length of the border is $135 \mathrm{~km}$. Volyn Region is genetically homogeneous. Ukrainians are estimated at $96.9 \%$ of the whole population of the region. There were insignificant waves of migration.

The Volyn Registry of Patients with MS was established in Volyn Regional Clinical Hospital in 2012. At the beginning of 2014 the Register included 810 patients with MS (101.0 per 100000$)$. This rate was the highest among other regions of Ukraine. In 2013 the prevalence of MS in Ukraine was 53.3 per 100000 .

To study MS risk factors in Volyn Region, special questionnaires were designed and distributed among all MS patients residing in Volyn Region. Patients were asked to indicate their sex, date and place of birth, height and weight, childhood infections and vaccinations, frequency of respiratory diseases before and after 18 years old, living conditions, distance to and duration of living near environmentally hazardous facilities, events of stress situations, diet preferences, time spend outdoor in summer and in winter, parental dates of birth and place of origin (Volyn region, south or eastern part of Ukraine or other countries), number of sisters and brothers. Results were obtained from 227 respondents including 154 women and 73 men of mean age $43 \pm 10.6$ years.

The control group included 105 healthy respondents (students, donors, workers and employees of the hospital) inhabiting Volyn Region. Study groups were matched by age and gender. The exclusion criteria for the control group were the demyelinating diseases, optic neuritis, dementia of different genesis, and incomplete questionnaires. The filling of questionnaires was voluntary. All patients and healthy controls gave their written consents prior to answering the questions under the requirements of the Helsinki Declaration.

The research protocol was approved by the Ethical Committee of O. O. Bogomolets National Medical University. The analytical epidemiological study was conducted to determine the most significant MS risk factors for patients in Volyn region.

Pearson's $\chi^{2}$ tests were performed to compare groups with and without MS. A two-tail $\mathrm{p}$ value of $<0.05$ was considered statistically significant for the study. $95 \%$ confidence intervals were calculated for each rate or ratio. The software Excel and Stata12 were used in the statistical calculations.

\section{Results}

Among MS patients, there was statistically significant greater number of individuals whose mothers had Volyn origin. The difference between groups of healthy controls and MS patients as to the paternal origin was non-significant. 
The average age of parents at the respondent's birth was considerably senior in patients with MS. The average age of mothers in this group was $27.2 \pm 5.2$ whilst the father's age was $29.9 \pm 5.9$ years old; the mother's age of healthy controls was $24.7 \pm 4.8$ years old whereas the father's age was $26.9 \pm 5.3$. The number of respondents who was born as a third child or more in the family was also higher in the MS group. As to the urban or rural origins, a statistically significant difference between the groups was not found. MS group included fewer subjects breastfed after the 1 year of age than the control group.

Patients with MS more often indicated the adverse environmental circumstances in anamnesis like the residence in the industrially contaminated areas (near industrial warehouses or factories, closed military areas and landfills) comparing to healthy controls. Most respondents with MS mentioned the presence of mobile- or TV- or radio re-translators and heavy traffic on roads near their houses. The duration of residence in such adverse conditions was longer among the patients with MS. It was $17.1 \pm 12.7$ years in comparison with $11.5 \pm 9.2$ years in healthy controls $(\mathrm{p}=0.033)$. The difference between the groups concerning the distance from home to the ecologically dangerous objects was not statistically significant.

Patients with MS spend less time outdoors than healthy controls (less than 1 hour in winter and 8 hours in summer), include fewer fruits and vegetables in the diet (less than 5 times a week), beef and poultry meat (less than 3times a week), berries (less than 3 times a week during the season), cereals (less than 4 times a week). As to pork, the significant difference among the groups was not found.

Chronic stressful situations in life were mostly reported by the patients with MS.

As to the other MS risk factors, namely, source of drinking water, passive smoking, overweight, there were no statistically significant differences between the study groups.

All answers received from questionaires of 227 patients with MS and 105 healthy controls were calculated in absolute numbers and percentage. The results of this investigation are summarized in the Table 1 and shown on the Fig. 1.

OR (95\% Cl)



Fig. 1. Risk Factors for Multiple Sclerosis in the Volyn Population

Patients with MS more frequently reported diseases like hepatitis, tonsillitis, chlamydiosis, acute respiratory viral infections (ARVI) for more than three times annually after 18 years old, and symptoms caused by herpes simplex virus. Statistically significant results were obtained only for AVRI, hepatitis and herpes simplex virus. 
Table 1

Risk Factors for multiple sclerosis in the Volyn population

\begin{tabular}{|c|c|c|c|c|c|c|}
\hline Risk Factors & $\begin{array}{l}\text { Group of Pati } \\
\text { total number } \\
\text { of obtained } \\
\text { answers }\end{array}$ & $\begin{array}{l}\text { nts with MS }(n=227) \\
\text { quantity and } \\
\text { percentage rate of } \\
\text { affirmative answers }\end{array}$ & $\begin{array}{l}\text { Affirmative } \\
\text { Answers in the } \\
\text { Healthy Controls } \\
\text { Group }(\mathbf{n}=105)\end{array}$ & $\begin{array}{c}\text { Odds Ratio and } \\
\text { Confidence } \\
\text { Interval (95\%) }\end{array}$ & $\chi^{2}$ & \\
\hline Mother of the Volyn origin & 124 & $97(78.2 \%)$ & $65(61.9 \%)$ & $2.2[1.2-4.0]$ & 7.3 & $\mathrm{p}=0.007$ \\
\hline Father of the Volyn origin & 124 & $81(65.3 \%)$ & $65(61.9 \%)$ & $1.2[0.68-2.0]$ & 0.3 & $\mathrm{p}=0.592$ \\
\hline $\begin{array}{l}\text { Maternal age (after } 27 \text { years } \\
\text { old) at birth of the respondent }\end{array}$ & 144 & $71(49.3 \%)$ & $30(28.6 \%)$ & $2.4[1.42-4.2]$ & 10.8 & $\mathrm{p}=0.001$ \\
\hline $\begin{array}{l}\text { Paternal age (after } 29 \text { years } \\
\text { old) at birth of the respondent }\end{array}$ & 141 & $76(54.3 \%)$ & $37(35.2 \%)$ & $2.1[1.28-3.6]$ & 8.4 & $\mathrm{p}=0.004$ \\
\hline $\begin{array}{l}\text { Respondents born as } \\
\text { the third child or more }\end{array}$ & 224 & $78(34.8 \%)$ & $12(11.4 \%)$ & $4.1[2.14-8.0]$ & 19.7 & $\mathrm{p}=0.000$ \\
\hline $\begin{array}{l}\text { Respondents born in } \\
\text { the urban areas }\end{array}$ & 207 & $59(28.5 \%)$ & $41(39.0 \%)$ & $0.6[0.38-1.0]$ & 3.6 & $\mathrm{p}=0.059$ \\
\hline $\begin{array}{l}\text { Respondents residing in } \\
\text { zones industrially polluted } \\
\text { and contaminated }\end{array}$ & 78 & $42(53.8 \%)$ & $28(26.7 \%)$ & $3.2[1.72-6.0]$ & 14.0 & $\mathrm{p}=0.000$ \\
\hline $\begin{array}{l}\text { Living near mobile, } \mathrm{TV} \text { and } \\
\text { radio retranslators }\end{array}$ & 78 & $28(35.9 \%)$ & $2(1.9 \%)$ & $28.8[6.61-125.9]$ & 37.7 & $\mathrm{p}=0.000$ \\
\hline $\begin{array}{l}\text { Domiciling near heavy } \\
\text { traffic roads }\end{array}$ & 78 & $7(9.0 \%)$ & $1(1 \%)$ & $10.3[1.23-85.2]$ & 6.9 & $\mathrm{p}=0.009$ \\
\hline $\begin{array}{c}\text { Breastfeeding for less than } \\
\text { one year }\end{array}$ & 158 & $112(70.9 \%)$ & $41(39 \%)$ & $3.8[2.26-6.4]$ & 26.3 & $\mathrm{p}=0.000$ \\
\hline $\begin{array}{l}\text { Time spending outdoors less } \\
\text { than one hour in winter }\end{array}$ & 187 & $52(27.8 \%)$ & $6(5.7 \%)$ & $6.4[2.63-15.4]$ & 20.6 & $\mathrm{P}=0.000$ \\
\hline $\begin{array}{l}\text { Time spending outdoors less } \\
\text { than eight hours in summer }\end{array}$ & 196 & $124(63.3 \%)$ & $38(36.2 \%)$ & $3.0[1.86-5.0]$ & 20.2 & $\mathrm{p}=0.000$ \\
\hline $\begin{array}{c}\text { Consumption of fruit and } \\
\text { vegetables less } \\
\text { than } 5 \text { times a week }\end{array}$ & 178 & $84(47.2 \%)$ & $33(31.4 \%)$ & $1.9[1.18-3.2]$ & 6.8 & $\mathrm{p}=0.009$ \\
\hline $\begin{array}{c}\text { Consumption of pork } 4 \text { and } \\
\text { more times a week }\end{array}$ & 166 & $67(40.4 \%)$ & $42(42.4 \%)$ & $0.9[0.55-1.5]$ & 0.1 & $\mathrm{p}=0.741$ \\
\hline $\begin{array}{l}\text { Consumption of beef less } \\
\text { than } 3 \text { times a week }\end{array}$ & 70 & $66(94.3 \%)$ & $30(28.6 \%)$ & $41.3[13.8-123.2]$ & 73.2 & $\mathrm{p}=0.000$ \\
\hline $\begin{array}{l}\text { Consumption of poultry meat } \\
\text { less than } 3 \text { times a week }\end{array}$ & 140 & $126(90.0 \%)$ & $76(72.4 \%)$ & 3.4 [1.71-6.9] & 12.9 & $\mathrm{p}=0.000$ \\
\hline $\begin{array}{c}\text { Consumption of berries less } \\
\text { than } 3 \text { times a week }\end{array}$ & 101 & $90(89.1 \%)$ & $46(43.8 \%)$ & $10.5[5.03-21.9]$ & 47.1 & $\mathrm{p}=0.000$ \\
\hline $\begin{array}{c}\text { Consumption of cereals less } \\
\text { than } 4 \text { times a week }\end{array}$ & 180 & $121(67.2 \%)$ & $34(32.4 \%)$ & $4.3[2.56-7.2]$ & 32.5 & $\mathrm{p}=0.000$ \\
\hline $\begin{array}{l}\text { Well is a source of } \\
\text { drinking water }\end{array}$ & 222 & $82(36.9 \%)$ & $34(32.4 \%)$ & $1.2[0.75-2.0]$ & 0.6 & $\mathrm{p}=0.421$ \\
\hline Centralized water supply & 222 & $109(49.1 \%)$ & $48(45.7 \%)$ & $1.1[0.72-1.8]$ & 0.3 & $p=0.567$ \\
\hline $\begin{array}{l}\text { Borehole is a source of } \\
\text { drinking water }\end{array}$ & 222 & $31(14.0 \%)$ & $23(21.9 \%)$ & $0.6[0.32-1.1]$ & 3.3 & $\mathrm{p}=0.071$ \\
\hline $\begin{array}{l}\text { Allergic reactions in } \\
\text { the respondent's anamnesis }\end{array}$ & 164 & $84(51.2 \%)$ & $47(44.8 \%)$ & $1.3[0.79-2.1]$ & 1.1 & $\mathrm{p}=0.301$ \\
\hline Chronic stress & 112 & $101(90.2 \%)$ & $61(58.1 \%)$ & $6.6[3.18-13.8]$ & 29.5 & $\mathrm{p}=0.000$ \\
\hline $\begin{array}{l}\text { Passive smoking in } \\
\text { the respondent's anamnesis }\end{array}$ & 197 & $75(38.1 \%)$ & $31(29.5 \%)$ & $1.5[0.88-2.4]$ & 2.2 & $\mathrm{p}=0.138$ \\
\hline Obesity & 207 & $79(38.2 \%)$ & $51(48.6 \%)$ & $0.7[0.41-1.1]$ & 3.1 & $\mathrm{p}=0.078$ \\
\hline
\end{tabular}


Among patients with MS there were fewer respondents with history of viral infections specific to childhood (measles, mumps, rubella, chickenpox, pertussis). However, statistically significant differences between the groups were reached only concerning chickenpox and rubella.

The group of patients with MS is characterized by a statistically significant smaller number of subjects having been immunized with DPT (diphtheria, pertussis, tetanus) vaccine and BCG. As to other vaccines, any difference was not statistically proved.

All answers about the history of childhood disease and immunization received from questionaires were summarized in the Table 2.

\section{Table 2}

History of Childhood Infectious Diseases and Immunization of Patients with MS and Healthy Respondents under Control

\begin{tabular}{|c|c|c|c|c|c|c|}
\hline \multirow[b]{2}{*}{ Infectious Disease } & \multicolumn{2}{|c|}{ Group of Patients with MS (n=227) } & \multirow[b]{2}{*}{$\begin{array}{c}\text { Group of } \\
\text { Healthy Controls } \\
(\mathrm{n}=105)\end{array}$} & \multirow[b]{2}{*}{$\begin{array}{l}\text { Odds Ratio and } \\
\text { Confidential } \\
\text { Interval }(95 \%)\end{array}$} & \multirow[b]{2}{*}{$\chi^{2}$} & \\
\hline & $\begin{array}{l}\text { total number of } \\
\text { obtained answers }\end{array}$ & $\begin{array}{c}\text { quantity and } \\
\text { percentage rate of } \\
\text { affirmative answers }\end{array}$ & & & & \\
\hline $\begin{array}{l}\text { ARVI in respondents } \\
\text { until } 18 \text { more than } \\
3 \text { times per year }\end{array}$ & 147 & $21(14.3 \%)$ & $8(7.6 \%)$ & $2.0[0.86-4.8]$ & 2.7 & $\mathrm{p}=0.102$ \\
\hline $\begin{array}{l}\text { ARVI in respondents } \\
\text { after } 18 \text { more than } \\
3 \text { times per year }\end{array}$ & 157 & $89(56.7 \%)$ & $5(4.8 \%)$ & $26.2[10.1-67.8]$ & 73.7 & $\mathrm{p}=0.000$ \\
\hline Measles & 196 & $69(35.2 \%)$ & $40(38.1 \%)$ & $0.9[0.54-1.4]$ & 0.2 & $\mathrm{p}=0.619$ \\
\hline Herpes simplex & 196 & $21(10.7 \%)$ & $4(3.8 \%)$ & $3.0[1.01-9.1]$ & 4.3 & $\mathrm{p}=0.039$ \\
\hline Infectious mononucleosis & 196 & $2(1.0 \%)$ & $2(1.9 \%)$ & $0.5[0.07-3.8]$ & 0.4 & $\mathrm{p}=0.523$ \\
\hline Mumps & 196 & $54(27.6 \%)$ & $30(28.6 \%)$ & $1.0[0.56-1.6]$ & 0.0 & $\mathrm{p}=0.851$ \\
\hline Scarlet fever & 196 & $10(5.1 \%)$ & $4(3.8 \%)$ & $1.4[0.42-4.4]$ & 0.3 & $\mathrm{p}=0.612$ \\
\hline Rubella & 196 & $16(8.2 \%)$ & $20(19 \%)$ & $0.4[0.19-0.8]$ & 7.7 & $\mathrm{p}=0.006$ \\
\hline Chickenpox & 196 & $86(43.9 \%)$ & $67(63.8 \%)$ & $0.4[0.27-0.7]$ & 10.9 & $\mathrm{p}=0.001$ \\
\hline Pertussis & 196 & $17(8.7 \%)$ & $15(14.3 \%)$ & $0.6[0.27-1.2]$ & 2.3 & $\mathrm{p}=0.132$ \\
\hline Hepatitis & 195 & $48(24.6 \%)$ & $7(6.7 \%)$ & $4.6[1.99-10.5]$ & 14.7 & $\mathrm{p}=0.000$ \\
\hline Rheumatism & 196 & $11(5.6 \%)$ & $6(5.7 \%)$ & $1.0[0.35-2.7]$ & 0.0 & $\mathrm{p}=0.971$ \\
\hline Tonsillitis & 194 & $59(30.4 \%)$ & $24(22.9 \%)$ & $1.5[0.85-2.6]$ & 1.9 & $\mathrm{p}=0.164$ \\
\hline Chlamydiosis & 196 & $13(6.6 \%)$ & $2(1.9 \%)$ & $3.7[0.81-16.5]$ & 3.2 & $\mathrm{p}=0.072$ \\
\hline \multicolumn{7}{|c|}{ Immunization (Vaccination) against } \\
\hline $\begin{array}{c}\text { Diphtheria, pertussis, } \\
\text { tetanus (DPT) }\end{array}$ & 201 & $145(72.1 \%)$ & $87(82.9 \%)$ & $0.5[0.3-1.0]$ & 4.3 & $\mathrm{p}=0.038$ \\
\hline BCG & 187 & $132(70.6 \%)$ & $91(86.7 \%)$ & $0.4[0.19-0.7]$ & 9.6 & $\mathrm{p}=0.002$ \\
\hline Measles, mumps, rubella & 187 & $105(56.1 \%)$ & $48(45.7 \%)$ & $1.5[0.94-2.5]$ & 2.9 & $\mathrm{p}=0.087$ \\
\hline Hepatitis & 187 & $60(32.1 \%)$ & $45(42.9 \%)$ & $0.6[0.38-1.0]$ & 3.4 & $\mathrm{p}=0.066$ \\
\hline
\end{tabular}

\section{Discussion}

Volyn region is a zone of high risk of MS. But prevalence rate differs (sometimes twofold) between districts of region [12]. This heterogenity does not clearly follows a latitudinal or other geographic basis. The high prevalence of MS on the territory of Volyn Region may be caused by some genetic characteristics of its population. Based on results of our survey, this phenomenon is explained by a maternal genome effect on the risk of MS. These results are similar with conclusions of others interracial observations of parent-of-origin effect in multiple sclerosis in Canada [13, 14] and effects of immigration [15].

Otherwise, recent studies, showing lack of genetic differences between monozygotic twins discordant for MS, highlighted the importance of environment [16]. Among the most investigated non-genetic MS risk factors are vitamin D levels, smoke influence, exposure to childhood infections, residing in polluted zones, nutritional habits, psycological stress etc [17]. 
The senior age of parents at the subjects'birth, presence of two or more older sibs, breastfeeding for less than 1 year give reasons to consider all these factors to be MS risk factors for Volyn population during the prenatal and an early childhood period in genetically susceptible individuals. The increased risk of MS may be associated with insufficient supplement of vitamin D3 in prenatal period. 25-hydroxyvitamin D through immunomodulatory effects increases the immunological self-tolerance and atttenuates initiation and progression of MS [18].

Our data demonstrates the protective role of sun exposure to the risk of MS. The ultraviolet radiation converts cutaneous 7-dehydrocholesterol to vitamin D3. Others studies also confirmed a link between sunlight and decreased MS risk [17, 19]. But insufficient outdoor time (particularly in the fresh air) for patients with MS may be evaluated as a risk factor of MS and simultaneously a result of patients' limited physical activities.

Any long-time exposure to environmentally adverse conditions is meaningful for the increased risk of MS development. This survey confirms our previous study results published in 2014 in Ukrainian Neurological Journal showing twofold prevalence of MS in the anthropogenically polluted areas of the region [20] and others studies in Canada, Japan, Australia, Europe which reveal the association between increased prevalence of MS and process of «Westernization», industry growth $[6,15,17,21]$.

The importance of the hyper caloric diet rich in fats, peculiar to the Volyn inhabitants, is an additional risk factor for MS and is confirmed in our survey. Anne Cross, M. D., of Washington University in St. Louis presented follow-up mechanistic data to Piccio et al. (2008) at the 2014 ACTRIMS-ECTRIMS meeting in Boston. Calorie restriction appears to reduce pro-inflammatory leptin and interleukin-6, while increasing adiponectin, an anti-inflammatory molecule. Thus, hypocaloric diet reduces the susceptibility to and severity of autoimmune encephalomyelitis in mice [22]. Otherwise, Rotstein and her colleagues, including Kassandra Munger, catalogued the diets of 480 people with MS. This was the first large, prospective, population-based study to investigate whether overall diet quality may contribute to the development of MS, and no evidence for such an association was found [23]. Until then, the general advice is: take in more vitamin D; avoid salty, fatty foods; eat more fruits and vegetables, and keep a balanced intake of nutrients [24]. Based on results of our survey, these advices are actual for Volyn patients too.

We cannot state that the chronic stress is a risk factor of MS as the increased anxiety and uneasiness occur in the pre-morbid period of MS.

Our survey does not reveal any association between MS risk and factors which were described as significant by other authors. The source of drinking water, passive smoking and overweight are not significant factors for MS patients residing Volyn region.

The higher incidence of ARVI (more than 3 times a year) and any herpes symptoms in the patients' group may be the result of reduced body resistance of patients with MS. The childhood diseases like chickenpox and rubella as well as DPT vaccination and BCG may have protective immune-regulating effects on the risk of MS development. These result are similar with another studies $[7,25]$. The mechanizm through which these two vaccines may exert effect remains unclear. Today, none of the immunazations are associated with higher risk of developing of MS [7].

\section{Conclusions}

- Volyn region is one of 25 regions of Ukraine with the highest prevalence of MS in Ukraine. But heterogenity of epidemiologic ratios of MS within one region puts a lot of questions to neurologist concerning factors of development of disease and mechanizm through which they may exert.

- Our survey defined risk and protective factors for MS which are special for Volyn inhabitants. Despite our study involved a small number of respondents, the influence of some factors on the development of MS, as previously described in the world medical research sources, was confirmed. We introduced a novel study of MS risk factors within Volyn Region. The Registry established in 2012 is being constantly updated and can be a database for a long-term retrospective study involving a large number of patients. 


\section{References}

[1] Ramagopalan, S. V., Sadovnick, A. D. (2011). Epidemiology of Multiple Sclerosis. Neurologic Clinics, 29 (2), 207-217. doi: 10.1016/j.ncl.2010.12.010

[2] Ebers, G., Sadovnick, A., Dyment, D., Yee, I., Willer, C., Risch, N. (2004). Parent-of-origin effect in multiple sclerosis: observations in half-siblings. The Lancet, 363 (9423), 1773-1774. doi: 10.1016/s0140-6736(04)16304-6

[3] Montgomery, S. M., Lambe, M., Olsson, T., Ekbom, A. (2004). Parental Age, Family Size, and Risk of Multiple Sclerosis. Epidemiology, 15 (6), 717-723. doi: 10.1097/01.ede.0000142138.46167.69

[4] Ascherio, A., Munger, K. L. (2007). Environmental risk factors for multiple sclerosis. Part I: The role of infection. Annals of Neurology, 61 (4), 288-299. doi: 10.1002/ana.21117

[5] Krone, B., Oeffner, F., Grange, J. M. (2009). Is the risk of multiple sclerosis related to the "biography" of the immune system? Journal of Neurology, 256 (7), 1052-1060. doi: 10.1007/s00415-009-5068-8

[6] Kira, J. (2012). Genetic and environmental backgrounds responsible for the changes in the phenotype of MS in Japanese subjects. Multiple Sclerosis and Related Disorders, 1 (4), 188-195. doi: 10.1016/j.msard.2012.05.003

[7] Farez, M. F., Correale, J. (2011). Immunizations and risk of multiple sclerosis: systematic review and meta-analysis. Journal of Neurology, 258 (7), 1197-1206. doi: 10.1007/s00415-011-5984-2

[8] Riccio, P., Rossano, R., Liuzzi, G. M. (2010). May Diet and Dietary Supplements Improve the Wellness of Multiple Sclerosis Patients? A Molecular Approach. Autoimmune Diseases, 2010, 1-12. doi: $10.4061 / 2010 / 249842$

[9] Johansen, C. (2004). Electromagnetic fields and health effects-epidemiologic studies of cancer, diseases of central nervous system and arrhythmia-related heart disease. Scandinavian Journal of Work, Environment \& Health, 30 (1).

[10] Harbo Poulsen, A., Stenager, E., Johansen, C., Bentzen, J., Friis, S., Schüz, J. (2012). Mobile Phones and Multiple Sclerosis - A Nationwide Cohort Study in Denmark. PLoS ONE, 7 (4), e34453. doi: 10.1371/journal.pone.0034453

[11] Granieri, E. (2006). Exogeneous factors in the aetiology of multiple sclerosis. Journal of Neurology, 6 (2), 141-146.

[12] Bobryk, N. V. (2014). Features of prevalence of multiple sclerosis in the world: review and personal observations on the territory of Volyn region. The practitioner, 1, 74-78.

[13] Ramagopalan, S. V., Yee, I. M., Dyment, D. A., Orton, S.-M., Marrie, R. A. et. al. (2009). Parent-of-origin effect in multiple sclerosis: Observations from interracial matings. Neurology, 73 (8), 602-605. doi: 10.1212/wnl.0b013e3181af33cf

[14] Warren, S., Svenson, L. W., Warren, K. G., Metz, L. M., Patten, S. B., Schopflocher, D. P. (2006). Incidence of Multiple Sclerosis among First Nations People in Alberta, Canada. Neuroepidemiology, 28 (1), 21-27. doi: 10.1159/000097852

[15] Orton, S.-M., Ramagopalan, S. V., Brocklebank, D., Herrera, B. M., Dyment, D. A., Yee, I. M. et. al. (2009). Effect of immigration on multiple sclerosis sex ratio in Canada: the Canadian Collaborative Study. Journal of Neurology, Neurosurgery \& Psychiatry, 81 (1), 31-36. doi: 10.1136/jnnp.2008.162784

[16] Hawkes, C. H. (2013). Multiple sclerosis genetics is dead. Multiple Sclerosis and Related Disorders, 2 (3), 156-161. doi: 10.1016/j.msard.2012.12.006

[17] Mansouri, B., Asadollahi, S., Heidari, K., Fakhri, M., Assarzadegan, F., Nazari, M., Divani, A. (2014). Risk factors for increased multiple sclerosis susceptibility in the Iranian population. Journal of Clinical Neuroscience, 21 (12), 2207-2211. doi: 10.1016/j.jocn.2014.04.020

[18] Milo, R., Kahana, E. (2010). Multiple sclerosis: Geoepidemiology, genetics and the environment. Autoimmunity Reviews, 9 (5), A387-A394. doi: 10.1016/j.autrev.2009.11.010

[19] Van der Mei, I. A. F. (2003). Past exposure to sun, skin phenotype, and risk of multiple sclerosis: case-control study. BMJ, 327 (7410), 316. doi: 10.1136/bmj.327.7410.316

[20] Bobryk, N. V., Sokolova, L. I. (2014). Ecological and population characteristics of epidemiological indicators of multiple sclerosis in districts of Volyn region. Ukrainian neurological journal, 3-4, 42-47.

[21] Etemadifar, M., Maghzi, A.-H. (2011). Sharp increase in the incidence and prevalence of multiple sclerosis in Isfahan, Iran. Multiple Sclerosis Journal, 17 (8), 1022-1027. doi: 10.1177/1352458511401460

[22] Cross, A. H. (2014). Leptin and other adipokines in EAE and multiple sclerosis. ACTRIMS-ECTRIMS, PS5.2.

[23] Rotstein, D. L., Chiuve, S., Chitnis, T., Fung, T., Munger, K. L. (2014). Dietary patterns not associated with risk of multiple sclerosis. ACTRIMS-ECTRIMS, PS5.3.

[24] McKelvey, C. (2014). Does Diet Matter in Multiple Sclerosis? Multiple Sclerosis Discovery Forum. doi: 10.7493/msdf.10.15345.1

[25] Hernan, M. A., Alonso, A., Hernandez-Diaz, S. (2006). Tetanus vaccination and risk of multiple sclerosis: A systematic review. Neurology, 67 (2), 212-215. doi: 10.1212/01.wnl.0000225079.51201.f9 